\title{
POLA INTERAKSI SOSIAL SUKU LAUT DI DESA AIR SENA, KECAMATAN SIANTAN TENGAH, KABUPATEN KEPULAUAN ANAMBAS, PROVINSI KEPULAUAN RIAU
}

\section{PATTERN OF SOCIAL INTERACTION OF SEA TRIBE PEOPLE AT AIR SENA VILLAGE SUBDISTRICT, SIANTAN TENGAH REGENCY, KEPULAUAN ANAMBAS, KEPULAUAN RIAU PROVINCE}

\author{
Miswanto, Billy Jenawi, Afrizal \\ Sekolah Tinggi Ilmu Sosial dan Ilmu Politik Raja Haji Tanjungpinang \\ Jln. Raja Haji Fisabililah, No. 48 Tanjungpinang \\ miswanto0584@gmail.com
}

Diterima tanggal 6 September 2018

Disetujui tanggal 26 Desember 2018

\begin{abstract}
This written discussed about people of Sea tribe at Air Sena Village Subdistrict, Kepulauan Anambas who live in the kajang side by side with people of Air Sena Village. Both of them make an intimate interaction, although not all of them can understand Mesuku language; a language that is used by people of Sea tribe, because most of Sea tribe people still use their native language. The question of this research is how are the patterns of social interaction among people of Sea tribe, and between people of Sea tribe and other community in Air Sena Village? The method of this research is descriptive qualitative. Source of primary data is obtained from deep interview and direct observation in research location. Result of this research is there are associative interaction such as cooperation, accommodation and assimilation that is manifested as mutual assistance, while dissociative process such as competition, contravention, and conflict. Symbolic interaction is a reaction of someone to other that induces some meaning and it delivered by use symbols from body and language. There is a good collaboration between people of Sea tribe and people of Air Sena Village, they help each other. Part of them is apathetic and not get participate in any organization, but people of Sea tribe still mingle with other community. On dissociative interaction, there is no conflict between people of Sea tribe and people of Air Sena Village.
\end{abstract}

Keywords: social interaction, symbolic interaction, Sea tribe, and people of Air Sena Village. 


\section{ABSTRAK}

Tulisan ini membicarakan masyarakat suku Laut yang tinggal di laut dengan menggunakan kajang di Desa Air Sena Kepulauan Anambas. Mereka hidup berdampingan dan berinteraksi "intim" dengan masyarakat Desa Air Sena walaupun tidak semua masyarakat sekitar bisa memahami bahasa Mesuku, bahasa yang digunakan oleh sebagian besar masyarakat suku Laut. Permasalahan yang diangkat dalam penelitian ini adalah bagaimana bentuk-bentuk interaksi sosial yang terjadi di antara sesama anggota (warga) kelompok suku Laut, serta di antara warga kelompok suku Laut dengan warga masyarakat lain di Desa Air Sena di tengah perbedaan bahasa. Metode yang digunakan dalam penelitian ini adalah deskriptif kualitatif. Sumber data primer diperoleh melalui teknik wawancara mendalam dan observasi secara langsung ke lokasi penelitian. Penelitian ini bermaksud untuk menunjukkan interaksi asosiatif berupa kerja sama, akomodasi dan asimilasi yang diwujudkan dalam bentuk gotong royong, serta proses disosiatif adanya persaingan, kontravensi, dan pertentangan. Wujud interaksi simbolik yang diobservasi berupa tanggapan seseorang terhadap orang lain melalui penggunaan simbol-simbol tubuh dan bahasa yang bermakna. Hasil penelitian menunjukkan bahwa kerja sama masyarakat suku Laut dengan masyarakat Desa Air Sena. Mereka hidup tolong-menolong meskipun sebagian masyarakat menunjukkan sikap apatis dan tidak berpartisipasi dalam organisasi kemasyarakatan. Sikap apatis tersebut secara disosiatif tidak menimbulkan pertentangan dan konflik antara masyarakat suku Laut dengan masyarakat Desa Air Sena.

Kata kunci: interaksi sosial, interaksi simbolik, suku Laut, dan masyarakat Desa Air Sena.

\section{A. PENDAHULUAN}

Suku Laut merupakan kelompok orang atau suatu komunitas yang tinggal di daerah pesisir. Kehidupan mereka bergantung pada pemanfaatan sumber daya laut secara langsung. Nelayan adalah mata pencaharian yang paling banyak ditekuni oleh masyarakat suku Laut. Dahulu suku Laut hidup mengembara secara turun-temurun, tetapi sekarang sebagian besar dari mereka sudah menetap di sekitar wilayah perairan Kepulauan Riau.

Suku Laut bukanlah penyebutan yang tunggal. Mereka yang tinggal di Pulau Bintan dan Anambas menyebut dirinya sebagai suku Laut. Namun, suku
Laut yang berada di sekitar Pulau Lingga menamakan diri sebagai orang Barok. Adapun yang mendiami Pulau Karimun menyebut dirinya sebagai orang Mantang. Selain itu, karena keseharian orang suku Laut dihabiskan di atas sampan (kajang), ada yang menyebut mereka dengan orang Sampan atau orang Kajang.

Secara umum, suku Laut memiliki ciri-ciri sebagai berikut: (1) berbentuk komunitas adat kecil tertutup dan homogen; (2) pranata sosial bertumpu pada hubungan kekerabatan; (3) pada umumnya tinggal di tempat yang terpencil yang secara geografis sulit dijangkau; (4) pada umumnya masih 
hidup dengan sistem ekonomi subsisten $^{1}$; (5) peralatan teknologinya sederhana; (6) kebergantungan pada lingkungan hidup dan sumber daya alam setempat relatif tinggi; (7) memiliki keterbatasan terhadap akses pelayanan sosial, ekonomi, dan politik.

Beberapa kajian yang telah dilakukan sebelumnya memperlihatkan bahwa suku Laut, baik yang hidup dalam kelompok-kelompok maupun yang tinggal berpencar-pencar, memiliki tingkat interaksi sosial yang masih rendah. Saat berinteraksi dengan masyarakat di sekitarnya, suku Laut cenderung menggunakan bahasa asli bahasa ibu (Mesuku) mereka yang tidak bisa dipahami oleh masyarakat Desa Air Sena. Perbedaan bahasa membatasi terbangunnya relasi sosial yang lebih intim antara suku Laut dengan masyarakat di sekitarnya.

Sebagian masyarakat suku Laut belum mengetahui penghitungan uang sehingga interaksi jual beli dilakukan dengan cara barter. Mereka akan membawa ikan hasil tangkapan ke patron (toke) secara langsung dan menukarkannya dengan barang kebutuhan pokok sehari-hari. Ketidakmampuan dalam menghitung uang ini berkaitan dengan pengetahuan

\footnotetext{
Subsisten yang dimaksud adalah karakteristik produksi yang hanya bertujuan untuk memenuhi kebutuhan sendiri atau keluarga. Orientasinya sekadar untuk kelangsungan hidup, bukan untuk dijual atau mengakumulasi hasil dalam bentuk uang. Hasil produksi tersebut biasanya ditukar dengan aneka kebutuhan pokok lain yang diperlukan.
}

membaca dan menghitung yang belum mereka kuasai dengan baik. Interaksi yang terbangun melalui barter dapat dikatakan sebagai bentuk kerja sama antara masyarakat suku Laut dengan masyarakat sekitar. Hubungan sosial berupa kerja sama yang ditandai dengan adanya pertukaran (barter) ditujukan untuk memperoleh imbalan yang sifatnya saling menguntungkan.

Zen (2002: 9) menjelaskan bahwa orientasi masyarakat suku Laut hanya kepada laut dan perutnya. Orientasi ini didasari hasrat memenuhi desakan kebutuhan karena kemiskinan yang mereka hadapi setiap hari. Selain itu, suku Laut belum memiliki akses yang memadai terhadap pelayanan publik seperti pelayanan umum dan sosial. Kondisi ini secara tidak langsung menjauhkan mereka dari kesempatan untuk meningkatkan kualitas hidup.

Saat ini, masih terdapat suku Laut yang belum dapat mengubah pola kehidupan mengembara yang telah dilakukan secara turun-menurun. Namun, ada pula di antara mereka yang telah hidup menetap di darat tetapi mereka tetap menyebut dirinya sebagai suku Laut dan tidak mengubah identitas sebagai masyarakat suku, seperti masyarakat suku Laut di Desa Air Sena, Kecamatan Siantan Tengah, Kabupaten Kepulauan Anambas, Provinsi Kepulauan Riau yang menjadi subjek dalam kajian ini. Populasi suku Laut di Desa Air Sena adalah 722 orang, terdiri dari 364 orang laki-laki dan 358 orang perempuan (Monografi Desa Air Sena, 2017). 
Handep, Vol. 2, No. 1, Desember 2018

Hanya sekitar 10\% dari populasi suku Laut di Desa Air Sena yang masih mempertahankan kebiasaan-kebiasaan leluhur. Mereka adalah kelompok suku Laut yang tidak mau meninggalkan kebiasaan-kebiasaan yang selama ini telah menjadi bagian dari kehidupan mereka di atas sampan.

Kepercayaan kelompok suku Laut masih bersifat animisme, misalnya percaya pada kekuatan gaib dan roh-roh nenek moyang mereka. Sementara kelompok suku Laut yang tinggal di darat sebagian besar menganut agama Kristen Protestan.

Suku Laut yang ada di Desa Air Sena menjaga kemurnian garis keturunannya. Mereka juga menganggap diri mereka sebagai orang Melayu asli, namun anggapan tersebut ditentang oleh warga masyarakat umumnya yang juga mengidentifikasi diri sebagai orang Melayu yang tingal di wilayah darat Desa Air Sena. Kelompok orang Melayu yang bermukim di darat kemudian membuat semacam ketentuan dan menetapkan sejumlah persyaratan yang mengatur tentang apa saja yang harus dilakukan dan yang tidak boleh dilakukan oleh orang Melayu. Pada umumnya ketentuan tersebut mengharuskan orang yang mengaku sebagai orang Melayu untuk mentaati hukum, aturan dan tata cara yang berlaku dalam agama Islam, tidak makan babi, sunat (bagi laki-laki), mengucapkan dua kalimat syahadat, menjalankan perkawinan dan perceraian secara Islam, salat lima waktu, turut serta membangun masjid di lingkungan desa, salat pada dua hari raya Islam (Idul Fitri dan Idul Adha), salat Jumat, menjalankan puasa di bulan Ramadan serta memberi zakat. Bagi orang-orang yang tidak menaati atau menjalankan ketentuan tersebut tidak bisa menyebut diri mereka sebagai orang Melayu.

Berbeda dengan penelitian yang mengatakan bahwa suku Laut memiliki tingkat interaksi yang rendah, Erwin (2014: 19) menjelaskan bahwa interaksi sosial antara masyarakat suku Laut dengan kelompok masyarakat lain di Desa Air Sena sudah berjalan dengan baik. Mereka melakukan kontak-kontak sosial dengan masyarakat sekitar melalui komunikasi yang terbangun di antara mereka. Kontak sosial dan interaksi tersebut dapat terjadi di mana saja, kapan saja, dan berlangsung di berbagai tempat, misalnya di laut ketika sedang mencari ikan, ataupun melalui pertemuan-pertemuan di kedai atau warung.

Bahasa Melayu adalah bahasa yang umumnya digunakan oleh masyarakat di Desa Air Sena dan dijadikan sebagai bahasa pergaulan sehari-hari. Sebagian masyarakat suku Laut di desa ini menguasai bahasa Melayu dan menggunakannya ketika berinteraksi dengan orang-orang yang berasal dari luar kelompok suku mereka. Kemampuan berbahasa Melayu di kalangan suku Laut dalam batas tertentu telah mempermudah terwujudnya interaksi sosial di antara kelompok suku Laut dan kelompok-kelompok lain yang hidup berdampingan di Desa Air Sena. Namun demikian, suku Laut tetap 
memiliki bahasa sendiri. Mesuku merupakan istilah bahasa masyarakat suku Laut yang tidak dimengerti oleh sebagian besar masyarakat Desa Air Sena.

Interaksi dapat diartikan sebagai suatu hubungan timbal balik yang terjadi antarindividu, antara individu dengan kelompok, ataupun antarkelompok. Kelompok suku Laut yang lebih memilih hidup berkelana, hanya hidup bersama keluarga atau tinggal di dalam kelompok sukunya sendiri tentu mengalami proses sosial dan membentuk pola interaksi yang berbeda dengan kelompok suku Laut yang hidup berbaur dengan warga masyarakat lain dalam suatu wilayah persekutuan hidup bersama, seperti di Desa Air Sena.

Kelompok suku Laut yang tinggal bersama keluarga ataupun kelompok sendiri cenderung akan merasa lebih nyaman karena mereka dipersatukan oleh budaya ataupun kebiasaan hidup yang relatif sama. Adapun kelompok suku Laut yang tinggal berdampingan dengan kelompok lain dituntut untuk dapat membangun interaksi sosial yang baik dengan orang atau kelompok lain yang memiliki perbedaan kebudayaan atau cara hidup sehingga tercipta kehidupan yang nyaman dan damai.

Berdasarkan kondisi tersebut, penelitian ini mengangkat permasalahan, yaitu pertama, bagaimana bentukbentuk interaksi sosial yang terjadi di antara sesama anggota (warga) kelompok suku Laut, serta di antara warga kelompok suku Laut dengan warga masyarakat lain di Desa Air Sena? Kedua, dengan mengacu pada konsep dan teori interaksionisme simbolik, permasalahan lainnya adalah bagaimana wujud dari interaksi simbolik yang terjadi antarawarga suku Laut dengan warga masyarakat lain di Desa Air Sena.

Metode yang digunakan dalam penelitian ini adalah metode kualitatif dan kajiannya bersifat deskriptif. Fenomena yang dilihat dan ditemukan di masyarakat sedapat mungkin digambarkan secara apa adanya, sesuai dengan kenyataan yang terjadi di masyarakat. Data primer dikumpulkan melalui teknik wawancara mendalam dengan masyarakat suku Laut, masyarakat Desa Air Sena, serta pengurus RW dan RT setempat. Selain wawancara, data primer juga bersumber dari observasi secara langsung ke lokasi penelitian.

Pengambilan informan dalam penelitian ini dilakukan dengan menggunakan teknik purposive sampling. Penentuan informan didasarkan pada kriteria yang telah ditetapkan peneliti, yaitu informan harus memahami tentang pola interaksi sosial masyarakat suku Laut di Desa Air Sena. Adapun yang dijadikan sampel dalam penelitian ini adalah sebanyak 15 informan. Para informan ini terdiri dari lima tokoh pemuda suku Laut, dua masyarakat desa setempat yang bukan berasal dari suku Laut, serta tiga tokoh agama dari suku Laut. Lima informan lainnya adalah perwakilan dari masyarakat suku Laut yang telah 
Handep, Vol. 2, No. 1, Desember 2018

melakukan interaksi dengan msyarakat setempat, tetapi mengalami hambatan karena perbedaan bahasa yang digunakan.

Analisis data dilakukan dengan cara memverifikasi setiap fenomena yang ada di masyarakat. Sesuai dengan tujuan dari pendekatan kualitatif yang berusaha mencari makna di balik fenomena yang terjadi, dalam proses analisis data setiap fenomena akan dicek kebenarannya dengan cara mencari pembuktiannya berdasarkan informasi yang disampaikan oleh informan dan pihak-pihak lain yang relevan. Proses pengolahan dan analisis data yang dilakukan secara berkelanjutan diharapkan dapat memberikan informasi secara holistik, Pemaparan data dilakukan dengan menggunakan narasi yang objektif.

Dalam kehidupan bermasyarakat terjalin hubungan timbal balik yang saling menguntungkan atau yang sering disebut sebagai interaksi sosial. Young dan Mack (dalam Soekanto, 2006: 61) mengatakan bahwa interaksi sosial adalah kunci dari semua kehidupan sosial. Tanpa adanya interaksi sosial tidak akan mungkin ada kehidupan bersama dalam masyarakat. Oleh karena itu, interaksi sosial merupakan syarat utama terjadinya aktivitas sosial. Interaksi sosial merupakan hubungan sosial dinamis yang menyangkut hubungan antara orang perorangan dan kelompok manusia interaksi sosial antara kelompok-kelompok manusia terjadi di antara kelompok tersebut sebagai suatu kesatuan dan biasanya tidak menyangkut pribadi anggotaanggotanya (Soekanto, 2006: 67). Dalam paparan tersebut dapat dijelaskan bahwa interaksi sosial adalah hubungan yang dinamis antara individu dengan kelompok, atau kelompok dengan kelompok.

Kebutuhan manusia untuk saling berhubungan merupakan gejala (fenomena) yang wajar dalam kehidupan bermasyarakat. Sebagimana hubungan timbal balik yang terjadi pada masyarakat suku Laut dan masyarakat Desa Air Sena, mereka saling berhubungan walaupun bahasa dalam berinteraksi sehari-hari di antara keduanya tidak saling dimengerti. Proses interaksi sosial terjadi di antara individu maupun kelompok yang berasal dari masyarakat suku Laut dan masyarakat Desa Air Sena

Kerja sama antara masyarakat suku Laut dengan masyarakat Desa Air Sena timbul karena adanya orientasi setiap individu yang ditujukan pada kelompoknya (in-group) dan kelompok lainnya (out-group) dalam mencapai tujuan. Fakta penting dalam kerja sama adalah kesadaran dari setiap individu pada suatu organisasi bahwa mereka memiliki kepentingan yang sama, disertai dengan pengetahuaan yang cukup dan pengendalian diri untuk memenuhi kepentingan-kepentingan tersebut.

Selain itu, kerja sama memiliki berbagai bentuk, yaitu kerja sama spontan yaitu kerja sama yang terjadi secara serta-merta; kerja sama langsung yang merupakan hasil dari perintah 
pihak tertentu; kerja sama kontak merupakan kerja sama atas dasar tertentu; serta kerja sama tradisional yang merupakan bentuk kerja sama sebagai unsur dari sistem sosial.

Akomodasi dapat diartikan sebagai suatu keadaan yang menunjukan terjadinya keseimbangan dalam interaksi antara individu-individu atau kelompok manusia, berkaitan dengan norma-norma sosial dan nilai-nilai sosial yang berlaku di masyarakat.

Menurut Koentjaraningrat (1996: 160) asimilasi merupakan suatu proses di mana pihak-pihak yang berinteraksi mengidentifikasi dirinya dengan kepentingan-kepentingan serta tujuan-tujuan kelompok. Faktor-faktor pendorong terjadinya asimilasi karena adanya toleransi, kesempatan yang seimbang di bidang ekonomi, menghargai kebudayaan asing, sikap terbuka dari golongan berkuasa dalam masyarakat, persaingan unsur kebudayaan, perkawinan campur, adanya musuh bersama di luar.

Menurut Philip Kotler (1999: 293) bahwa persaingan merupakan suatu proses sosial, di mana individu atau kelompok-kelompok manusia yang bersaing mencari keuntungan melalui bidang-bidang kehidupan. Bentuk persaingan ekonomi dapat berupa persaingan kebudayaan, persaingan kedudukan dan peranan, serta persaingan ras.

Selanjutnya, Philip menjelaskan bahwa kontravensi (contravention) dapat diartikan sebagai interaksi sosial yang sifatnya berada antara persaingan dan pertentangan. Bentuk interaksi ini ditandai dengan gejala-gejala ketidakpastian mengenai diri seseorang, atau suatu rencana dan perasaan yang tidak suka disembunyikan, serta kebencian dan keragu-raguan terhadap kepribadian seseorang. Kontravensi dapat terwujud dalam perbuatan penolakan, keengganan, perlawanan, perbuatan yang menghalang-halangi, protes, perbuatan keras dan mengacaukan rencana pihak lain, seperti menyangkal pertanyaan orang lain, memaki-maki melalui surat, mencerca, serta memfitnah. Perbuatan kontravensi antara lain adalah penghasutan, sementara perbuatan yang taktis misalnya mengejutkan lawan, mengganggu dan membingungkan pihak lain.

Menurut Sabian Utsman (2007: 28), pertentangan atau pertikaian (conflict) merupakan suatu proses sosial di mana individu atau kelompok berusaha memenuhi tujuan dengan jalan menentang pihak lawan yang disertai dengan ancaman dan kekerasan. Termasuk di dalamnya adalah pertentangan pribadi, pertentangan rasial, pertentangan kelas sosial, dan pertentangan politik.

Salah satu faktor yang mendasar dari interaksi sosial adalah komunikasi. Menurut Soekanto (2006: 76-78) arti penting dari komunikasi adalah seseorang memberikan tafsiran terhadap perilaku orang lain yang berwujud pembicaraan, gerak-gerik badaniah, atau aspek lainnya. Dalam komunikasi terdapat unsur-unsur 
Handep, Vol. 2, No. 1, Desember 2018

seperti berikut, yakni pengirim dan penerima berita; berita yang dikirimkan; media atau alat pengirim berita; sistem simbol yang digunakan untuk menyatakan berita.

Kerja sama untuk mencapai suatu tujuan bersama didasari oleh komunikasi antarindividu yang melakukan interaksi sosial. Dalam hal ini komunikasi memiliki arti yang sangat penting karena dengan adanya komunikasi sikap dan perasaan seseorang ataupun suatu kelompok dapat diketahui oleh orang ataupun kelompok yang lain.

Komunikasi antarmanusia merupakan kegiatan mahluk sosial dalam suatu kelompok kecil ataupun kelompok besar yang ada pada organisasi masyarakat ataupun bangsa. Karena sangat pentingnya komunikasi bagi kehidupan manusia, maka manusia disebut sebagai homo comunicus. Artinya, manusia sebagai mahluk sosial yang selalu mengadakan hubungan dan interaksi dengan sesamanya, karena mereka saling memerlukan dan hanya bisa berkembang melalui komunikasi. Interaksi sosial terjalin karena adanya komunikasi yang akan memudahkan manusia hidup bermasyarakat.

Interaksi simbolik menekankan pada hubungan antara simbol dengan interaksi. Menurut Blumer, interaksi simbolik pada intinya menjelaskan tentang kerangka referensi untuk memahami bagaimana manusia bersama dengan orang lain menciptakan dunia simbolik dan bagaimana cara dunia membentuk perilaku manusia.
Interaksi simbolik ada karena adanya ide-ide dasar dalam membentuk makna yang berasal dari pikiran manusia (mind) mengenai diri (self); hubungannya di tengah interaksi sosial; dan tujuan akhirnya untuk memediasi serta menginterpretasi makna di tengah masyarakat (society) di mana individu tersebut menetap (dalam George Ritzer, 2012: 629-632).

Pemaknaan terhadap sesuatu timbul dari interaksi. Tidak ada cara lain untuk membentuk makna, selain dengan membangun hubungan dengan individu lain melalui interaksi. Blumer (dalam Ritzer, 2012: 687) selanjutnya menjelaskan bahwa istilah interaksionalisme simbolik menunjukan sifat khas dari interaksi antarmanusia. Kekhasannya adalah bahwa manusia saling menerjemahkan dan saling mendefinisikan tindakannya, bukan hanya sekadar memberi reaksi atau tindakan seorang terhadap orang lain. Tanggapan seseorang terhadap orang lain tidak dibuat secara langsung melainkan didasari oleh "makna" yang diberikan terhadap tindakan seseorang pada akhirnya.

Interaksi sosial pada hakikatnya adalah interaksi simbolik. Manusia berinteraksi dengan yang lain dengan cara menyampaikan simbol. Orang lain yang akan memberikan makna atas simbol tersebut.

\section{B. HASIL DAN BAHASAN}

Pola interaksi menggambarkan suatu hubungan sosial yang dinamis yang menyangkut hubungan 
antarindividu, antarkelompok manusia, maupun antara individu dengan kelompok manusia lainnya. Interaksi diartikan sebagai sebuah hubungan timbal balik karena di dalamnya terdapat aksi berupa tindakan dan reaksi terhadap tindakan individu atau kelompok lain.

Pertemuan fisik semata yang terjadi antarindividu di dalam suatu kelompok tidak akan menghasilkan pergaulan hidup tanpa adanya komunikasi dan kerja sama untuk mencapai tujuan bersama. Interaksi sosial juga kerap diwarnai persaingan dan pertikaian. Dengan demikian dapat dikatakan bahwa interaksi sosial merupakan dasar dari proses sosial dan memperlihatkan adanya hubungan-hubungan yang dinamis.

Proses interaksi dapat menggambarkan bagaimana caranya hubungan-hubungan sosial dibangun melalui pertemuan antarindividu dan antarkelompok yang kemudian menentukan sistem dan bentuk hubungan tersebut. Selain itu penting pula untuk mencermati apa yang akan terjadi apabila di dalam proses interaksi itu terjadi perubahan-perubahan sikap atau perilaku individu yang akan menyebabkan perubahan pada cara atau pola hidup yang telah ada.

Proses interaksi antara masyarakat suku Laut, baik yang sudah menetap di darat maupun yang masih tinggal di kajang di Desa Air Sena terhadap masyarakat setempat cenderung tidak berjalan seperti masyarakat pada umumnya karena bahasa yang digunakan oleh masyarakat suku Laut baik yang sudah menetap di darat maupun mereka yang masih tinggal di kajang, ketika berinteraksi dengan masyarakat Desa Air Sena sebagian besar tidak bisa dimengerti oleh masyarakat. Proses interaksi yang bersifat positif merupakan interaksi yang menuju arah persatuan (proses asosiatif). Sebaliknya, proses yang negatif adalah interaksi yang menuju arah perpecahan (proses disosiatif).

Interaksi antara suku Laut dengan masyarakat di Desa Air Sena tidak terlepas dari proses yang bersifat asosiatif maupun disosiatif. namun dalam penelitian ini penulis hanya memfokuskan diri untuk membahas bentuk-bentuk interaksi sesuai dengan teori dan konsep yang telah dikemukakan di bagian sebelumnya.

\section{Proses Assosiatif: Kerja Sama, Akomodasi, dan Asimilasi}

Proses asosiatif merupakan pola interaksi yang bersifat menguatkan ikatan sosial. Bentuk interaksi yang seperti ini cenderung terjadi secara berkelanjutan karena didasarkan kepada kebutuhan yang nyata. Contoh, kerja sama yang didasarkan penghargaan terhadap kebudayaan masing-masing, ataupun terhadap pendapat masyarakat yang menjadi anggota baru dalam kelompok. Contoh lainnya adalah kerja sama dalam pertukaran informasi yang dapat mempermudah penyesuaian dan penerimaan anggota baru. Pada proses interaksi yang seperti ini kaidah-kaidah, nilai, dan norma sosial yang berlaku 
Handep, Vol. 2, No. 1, Desember 2018

dijadikan sebagai pedoman, tanpa ada paksaan secara fisik dan mental.

Bentuk interaksi sosial yang paling sering dilakukan di Desa Air Sena adalah kerja sama, karena pada dasarnya setiap individu atau kelompok tertentu yang ada di desa ini melaksanakan interaksi sosial dalam rangka memenuhi kepentingan bersama. Berikut ini adalah deskripsi mengenai kerja sama yang terdapat di Desa Air Sena.

\section{a. Gotong Royong}

Salah satu wujud nyata dari kerja sama yang dilakukan oleh masyarakat suku Laut dan penduduk lain di Desa Air Sena adalah gotong royong. Aktivitas ini bisa berupa membersihkan jalan desa dari tumpukan tanah dan pasir bangunan, terutama di musim hujan. Gotong royong dilakukan pula oleh masyarakat untuk memperbaiki jalan-jalan desa yang belum memenuhi standar, khususnya yang merupakan akses menuju ke sekolah.

Keterlibatan masyarakat suku Laut yang bermukim di Desa Air Sena dalam kegiatan gotong royong cenderung rendah, artinya bukan berarti masyarakat suku Laut tidak melakukan kegiatan gotong royong, akan tetapi harus ada yang menggerakkan mereka untuk melakukan gotong royong atau kegiatan-kegiatan di tengah-tengah masyarakat. Di samping itu, mereka jarang mengikuti aktivitas ini karena kesibukan mereka melaut atau pergi mencari ikan untuk memenuhi kebutuhan hidup sehari-hari. Terlebih di antara kelompok suku Laut tersebut masih ada yang tidak menetap di darat, tinggal di dalam sampan-sampan mereka. Hanya sebagian kecil dari mereka yang menyempatkan diri ikut serta dalam kegiatan gotong royong bersama-sama dengan anggota masyarakat Desa Air Sena.

Selain disebabkan karena kesibukan mencari nafkah, suku Laut di Desa Air Sena terkadang tidak mendapatkan informasi dari perangkat desa mengenai rencana diadakannya gotong royong di desa tersebut. Kurangnya atau ketiadaan informasi ini menjadi alasan untuk tidak terlibat secara aktif di dalam aktivitas gotong royong.

Ada kecenderungan masyarakat suku Laut mau ikut serta dalam kegiatan gotong royong ketika ada yang menggerakkan. Tampaknya, para pemuda suku Laut relatif lebih mudah untuk digerakkan karena mereka cukup aktif melibatkan diri dalam aktivitas gotong royong, bergabung dengan pemuda-pemuda dari luar suku mereka yang ada di desa itu.

Rendahnya partisipasi masyarakat suku Laut yang ada di Desa Air Sena dalam aktivitas gotong royong pada kenyataannya telah mengurangi peluang mereka membangun interaksi sosial dengan anggota masyarakat lainnya dan menjadi kendala dalam proses pembauran di antara kelompokkelompok sosial yang berbeda. 


\section{b. Sistem Barter}

Di dalam memenuhi kebutuhan sehari-hari, masyarakat suku Laut masih mempraktikkan sistem barter, yaitu menukarkan hasil tangkapan dari laut dengan barang-barang kebutuhan sehari-hari. Kutipan hasil dari wawancara dengan informan berikut ini menggambarkan adanya pertukaran tersebut.

"Kadang kalau kami mau melaut tidak ada minyak solar kami pinjam dulu dengan tetangga yang memiliki minyak solar. Setelah kami pulang dari melaut hasilnya kami jual atau tukar kebutuhan pokok yang kami perlukan Ya kadang untuk bayar hutang minyak tadi kami cukup kasih ikan saja" (wawancara Laukuto, Desa Air Sena, 15 Januari 2018).

Pernyataan di atas dapat dikemukakan bahwa masyarakat suku Laut masih menggunakan sistem barter dalam melakukan transaksi ekonomi.

Anggota masyarakat Desa Air Sena di luar kolompok suku Laut bisa memaklumi kondisi ini dan tidak keberatan untuk melakukan pertukaran barang. Apalagi jika barang yang ditukarkan dengan hasil tangkapan itu adalah barang-barang yang benar-benar dibutuhkan dan mendesak sifatnya.

\section{c. Pemilihan Jodoh}

Dewasa ini masyarakat suku Laut tidak lagi terlalu taat pada aturan adat perkawinan yang diturunkan dari generasi sebelumnya (orang tuanya), khususnya dalam memilih dan menentukan pasangan hidup. Kini, mereka sudah cenderung bebas menentukan pasangan hidupnya, tidak ada lagi keharusan untuk menikah dengan orang yang berasal dari kelompok suku yang sama.

Hasil wawancara yang menggambarkan adanya perkawinan di antara mereka yang berasal dari suku Laut dengan orang yang berasal dari luar kelompok sukunya.

"Kalau saya asli orang Kajang dekat Tanjungpinang, Mak dan Bapak saya asli orang Cina dekat Balik Motor dekat Pasar Kajang. Saya nikah dengan suami saya, ya saya ikut suami saya dekat Aek Sena ni. Dia keturunan agama Budha. Saya keturunan agama Kristen" (wawancara Arinandi, Desa Air Sena, 17 Januari 2018).

Pernyataan dari kutipan wawancara tersebut menggambarkan bahwa masyarakat suku Laut Desa Air Sena tidak lagi sepenuhnya patuh pada adat istiadat perkawinan yang mengharuskan mereka menikah dengan orang yang berasal dari kelompok yang sama. Kini, mereka sudah bisa melakukan perkawinan dengan orang-orang yang berasal dari luar kelompok sukunya (perkawinan silang).

\section{d. Balas Jasa dan Bantuan Pertolongan Pada Peristiwa- Peristiwa Khusus}

Masyarakat suku Laut di Desa Air Sena mengenal konsep balas jasa melalui pemberian hasil tangkapan (ikan) kepada orang-orang yang pernah membantu mereka. Berikut kutipan 
Handep, Vol. 2, No. 1, Desember 2018

wawancara yang menggambarkan tentang balas jasa yang dilakukan suku Laut.

"Kadang kami mencari ikan perginya jauh-jauh. sampai satu minggu baru pulang ke rumah. kadang di laut dihantam gelombang besar dan angin kencang. Kami biasanya numpang berlabuh pompongnya di daerah Palah, karena daerah itu agak aman untuk berlabuh dan beristirahat.Kadang kasih ikan dengan secara gratis ke masyarakat di desa kami. Numpang berlabuh, karena tak enak juga tak kasih (balasan). Kita sudah numpang di tempatnya" (wawancara Karyo, Desa Air Sena 21 Januari 2018).

Kutipan hasil wawancara dengan warga desa dari suku Laut ini memperlihatkan bahwa terkadang di tengah-tengah aktivitas melaut yang mereka lakukan terdapat kendala alam yang memaksa mereka harus menghentikan aktivitas dan mencari tempat berlindung. Mereka kemudian akan singgah atau berlabuh untuk beristirahat dan menyandarkan kapal mereka di pulau-pulau teraman, di antaranya masih berada di wilayah Desa Air Sena. Balasan atas pemberian "tumpangan", mereka kemudian membalasnya dengan memberi sebagian dari hasil tangkapan mereka untuk warga setempat. Di sinilah terbangun interaksi dengan masyarakat di luar dari komunitas mereka.
Kerja sama yang didasarkan balas jasa juga berlaku ketika para nelayan suku Laut membantu menarik pompon (sejenis perahu) milik nelayan di luar kelompok sukunya yang mengalami kerusakan di tengah laut, sehingga bisa kembali dibawa pulang. Bantuan ini diberikan karena nelayan suku Laut juga pernah medapatkan pertolongan yang sama ketika pompon mereka mengalami kerusakan.

Bantuan tenaga secara sukarela dalam rangka saling membantu dalam kehidupan bermasyarakat juga ditunjukkan masyarakat suku Laut di saat terjadi peristiwa-peristiwa khusus. Misalnya, ketika ada warga di Desa Air Sena yang kerabatnya meninggal dunia, mereka membantu menggali lubang kubur. Ketika ada hajatan pernikahan, mereka mambantu mendirikan tenda. Berbagai bentuk pertolongan tersebut menunjukkan masyarakat suku Laut memiliki kepedulian terhadap warga masyarakat lain yang berasal dari suku yang berbeda dengan mereka. Dalam kondisi seperti ini tercipta pola interaksi sosial yang baik.

Hasil penelitian menunjukkan bahwa partisipasi masyarakat suku Laut di Desa Air Sena dalam organisasi sosial kemasyarakatan yang terdapat di desa tersebut cenderung rendah, artinya keterlibatan mereka dalam organisasi sosial kemasyarakatan bukan atas dasar kesadaran individu atau kelompok, melainkan karena diajak untuk ikut serta terlibat dalam kegiatan organisasi kemasyarakatan oleh pemuda maupun masyarakat yang berada di Desa Air 
Sena. Apabila ada pemilihan kepengurusan dalam organisasi di tingkat desa, warga masyarakat suku Laut tetap diikutsertakan, baik sebagai kandidat ketua maupun anggota pengurus organisasi. Hal ini merupakan bentuk penghargaan terhadap keberadaan kelompok suku Laut sebagai bagian dari warga masyarakat Desa Air Sena. Terlihat bahwa organisasi-organisasi yang ada di desa tersebut tidak dapat berjalan dengan baik. Salah satu penghambatnya adalah komunikasi yang tidak lancar, karena tidak terjalin komunikasi antara suku Laut dengan warga Desa Air Sena. Kegagalan komunikasi terjadi ketika bahasa yang digunakan oleh orang suku Laut sering kurang dimengerti oleh masyarakat Desa Air Sena.

Gambaran tentang interaksi antara suku Laut dengan kelompok masyarakat di Desa Air Sena, seperti yang telah diuraikan di atas, memperlihatkan bahwa hanya sebagian dari warga suku Laut yang melakukan interaksi dengan masyarakat desa. Peristiwa tersebut pun terbatas pada ruang-ruang tertentu, misalnya dalam transaksi ekonomi (barter). Kondisi yang demikian menimbulkan kesan masyarakat suku Laut jarang berbaur dengan warga lain.

Salah seorang informan menambahkan warga dari suku Laut tidak mau berbaur dan berinteraksi dengan masyarakat Desa Air Sena karena mereka menetap di sampan. Warga setempat berharap kelompok suku Laut bisa lebih aktif dalam organisasi dan kegiatan desa, serta dapat berbaur di tengah-tengah masyarakat sebagaimana warga masyarakat lainnya. Meskipun terjadi kesenjangan interaksi antara warga masyarakat suku Laut dengan warga desa lainnya, tetapi warga masyarakat suku Laut tetap dilibatkan dalam setiap kegiatan yang diselenggarakan di tingkat desa.

Asimilasi yang dimaksud di sini adalah bagaimana warga masyarakat Desa Air Sena yang terdiri atas kelompok-kelompok yang berbeda latar belakang budayanya dapat saling menghargai satu sama lain. Penghargaan terhadap masing-masing kelompok dan budayanya ini bertujuan untuk membentuk kehidupan kemasyarakatan yang aman dan nyaman.

Pada dasarnya, masyarakat Desa Air Sena dapat menerima kehadiran orang atau kelompok lain yang berbeda latar belakang budayanya. Sebagaimana yang terjadi pada masyarakat suku Laut yang merupakan masyarakat pendatang yang sebelumnya mereka tinggal di laut dan sekarang sebagian sudah tinggal di darat dan masyarakat menerima kehadiran mereka dengan baik. Meskipun terkadang ada segelintir anggota masyarakat yang mengekspresikan ketidaksukaan terhadap kebiasaan yang dimiliki oleh kelompok lain, tetapi hal tersebut tidak ditunjukkan secara berlebihan. Beberapa kasus yang pernah terjadi, misalnya saling mengejek di antara kelompok yang berbeda, atau merasa terganggu di saat salah satu kelompok 
Handep, Vol. 2, No. 1, Desember 2018

merayakan hari besar agama mereka dengan membunyikan musik sekeraskerasnya. Kasus-kasus seperti itu dianggap tidak mengganggu keharmonisan hubungan di antara warga masyarakat Desa Air Sena. Mereka tetap berupaya untuk menguatkan sikap toleransi dan menciptakan kenyamanan dalam hidup bermasyarakat.

\section{Proses Disosiatif: Persaingan, Kontravensi, dan Pertentangan}

Disosiatif merupakan pola interaksi sosial yang mengarah pada pertentangan dan konflik yang bisa membuat perpecahan dalam kehidupan bermasyarakat. Bentuk interaksi sosial yang disosiatif adalah persaingan, kontravensi (contravention) dan pertentangan (conflict).

Persaingan yang dapat ditemukan pada masyarakat Desa Air Sena adalah persaingan di bidang ekonomi, yang pada akhirnya berkaitan pula dengan persaingan untuk meningkatkan kedudukan atau status sosial.

Adanya perbedaan dalam tingkat pendapatan yang diperoleh dari aktivitas ekonomi yang mereka kerjakan sehari-hari mendorong munculnya persaingan di kalangan suku Laut di Desa Air Sena. Wujudnya dapat dilihat dari saling berlomba dalam memperoleh hasil tangkapan ikan serta memperluas ukuran keramba agar dapat memelihara ikan dalam jumlah yang lebih banyak.

Persaingan yang juga terjadi di kalangan suku Laut Desa Air Sena adalah saling berlomba dalam memperindah tampilan rumah dan sampan. Bukan sekadar supaya lebih nyaman untuk ditinggali dan saat dipergunakan untuk bekerja, keindahan dan kemewahan rumah dan sampan yang dimiliki seseorang sering kali berhasil mendatangkan pujian bagi pemiliknya. Lebih jauh lagi, kepemilikan atas sejumlah barang yang bernilai tersebut dapat menentukan status sosial seseorang, sesuatu yang dianggap penting bagi suku Laut.

Meskipun persaingan seperti ini tidak mencolok, faktanya dapat ditemukan pada suku Laut yang berdiam di darat. Persaingan yang terjadi dalam kehidupan sehari-hari warga suku Laut tidak mengarah kepada konflik yang terbuka karena mereka tetap menjaga hubungan baik antarsesama anggota kelompok.

Kontravensi (contravention) merupakan proses sosial yang berada di antara persaingan dan pertentangan/ pertikaian. Kontravensi ditandai dengan adanya gejala-gejala ketidakpastian mengenai diri seseorang, perasaan tidak suka yang disembunyikan, ataupun kebencian dan keragu-raguan terhadap kepribadian seseorang.

Perkelahian karena adanya perselisihan pendapat pernah terjadi antara warga suku Laut dengan warga dari Desa Air Sena. Namun kasus-kasus seperti ini tidak lagi terjadi saat ini. Pengalaman di masa lalu membuat warga masyarakat desa ini belajar untuk menghindari perselisihan dan menjaga hubungan baik di antara mereka. 
Kontravensi yang terwujud dalam sikap ragu-ragu terhadap kepribadian seseorang biasanya muncul karena adanya hasutan dan intimidasi. Bagi suku Laut yang sibuk bekerja dan jarang berinteraksi dengan warga sekitar, kesempatan untuk bertemu dengan warga desa setempat relatif terbatas, sehingga kecil kemungkinan terjadi hasutan atau intimidasi terhadap mereka.

Perbedaan-perbedaan yang ada di antara individu maupun kelompok sering dianggap sebagai salah satu faktor penyebab pertentangan atau konflik, yang menimbulkan keinginan untuk saling menghancurkan. Pertentangan (conflict) adalah bentuk interaksi yang terjadi akibat adanya pertikaian (perkelahian) yang diakibatkan adanya ketidaksukaan seseorang terhadap orang atau pihak lain, dan bisa juga karena perbedaan kepentingan.

Di antara warga masyarakat Desa Air Sena, konflik yang terjadi umumnya terkait dengan sengketa lahan. Misalnya, pernah ada warga dari kelompok suku Laut yang tinggal di darat membangun rumah di atas lahan yang bukan miliknya. Kasuskasus yang terjadi di Desa Air Sena tidak sampai menimbulkan permusuhan yang berkepanjangan, apalagi hingga mengakibatkan perpecahan di masyarakat. Penyelesaian konflik lazimnya dilakukan secara kekeluargaan dan melalui musyawarah. Peran perangkat desa sangat penting dalam memberikan pemahaman dan penjelasan yang bisa diterima oleh semua pihak yang sedang berkonflik.

\section{Interaksi Simbolik Masyarakat di Desa Air Sena}

Tanggapan seseorang terhadap orang lain tidak dibuat secara serampangan melainkan didasari oleh "makna" yang diberikan terhadap tindakan seseorang. Hal ini merupakan penerjemahan makna yang dilakukan oleh suku Laut terhadap tindakan yang diberikan oleh masyarakat sekitar terhadapnya. Makna disampaikan melalui simbol-simbol gerak tubuh, bahasa. Namun hasil dari penafsiran makna bisa saja berlainan atau berbeda antara satu dengan lainnya, karena hal ini bergantung pada proses berpikir dan kemampuan yang dimiliki masingmasing anggota kelompok suku Laut Desa Air Sena. Selain itu juga, simbol yang digunakan dalam berinteraksi bisa diperlihatkan dalam bentuk gestur dalam membangun interaksi sosial atau berkomunikasi, ini merupakan salah satu cara yang digunakan dalam berkomunikasi dengan masyarakat Desa Air Sena.

Interaksi simbolik menekankan pada proses pemaknaan atas tindakan seseorang sebagai dasar dalam memberikan respon balik atau tanggapan. Proses ini terjadi pula dalam interaksi antara warga masyarakat suku Laut dengan warga masyarakat lain di Desa Air Sena. Masyarakat suku Laut menerjemahkan makna dari tindakan masyarakat sekitar yang disampaikan kepada mereka. 
Handep, Vol. 2, No. 1, Desember 2018

Interaksi antarindividu dipenuhi dengan penggunaan simbol-simbol. Sebagaimana yang terjadi ketika masyarakat suku Laut dan masyarakat Desa Air Sena berinteraksi, di antara keduanya terkadang menunjukan simbol dalam bentuk gestur dalam berkomunikasi. Pihak-pihak yang terlibat dalam interaksi akan berusaha untuk saling memahami maksud atau makna dari tindakan yang dilakukan oleh masing-masing pihak. Interaksi antarwarga suku Laut dengan warga masyarakat lain Desa Air Sena bukanlah sebuah proses yang terjadi di saat masyarakat sekitar memberikan stimulus secara spontan kepada warga suku Laut. Interaksi merupakan rangkaian proses yang dimulai dari pemberian stimulus oleh warga sekitar, kemudian diterima oleh warga suku Laut, disusul dengan adanya respon, dan selanjutnya menyampaikan tanggapan warga suku Laut ke warga masyarakat sekitar. Proses yang sama terjadi pula sebaliknya. Sesuai dengan teori interaksi simbolik, pemaknaan merupakan penengah di antara stimulus, sedangkan respon merupakan kunci utama dari interaksi.

Bahasa yang digunakan oleh masyarakat sekitar ketika berinteraksi dengan warga suku Laut merupakan simbol yang penting dalam proses interaksi. Jika bahasa yang digunakan oleh warga sekitar adalah bahasa Melayu, komunikasi tatap muka akan menjadi lebih efektif. Karena terdapat cukup banyak warga suku Laut yang kurang menguasai bahasa Melayu, simbol-simbol lain seperti ekspresi wajah dan gestur yang bisa mendukung penyampaian makna wajib digunakan.

\section{PENUTUP}

Hasil penelitian sebagaimana yang sudah dipaparkan di atas bahwa saran yang bisa disampaikan adalah:

1. Bagi masyarakat suku Laut Desa Air Sena untuk dapat meluangkan waktunya guna mengikuti kegiatan maupun organisasi yang bersifat kemasyarakatan agar tercipta kebersamaan dan saling kerja sama, dan hendaknya untuk sedikit terbuka dengan masyarakat yang ada dan tidak saling menghindar ketika bertemu sehingga saling menjaga hubungan sosialnya.

2. Bagi masyarakat sekitar supaya membaur dengan masyarakat suku Laut, agar masyarakat suku Laut, tidak merasa kurang percaya diri atau segan di saat bertemu di jalan maupun untuk melakukan silaturahmi di rumahnya, sehingga mudah terciptanya pola interaksi sosial yang baik.

\section{DAFTAR SUMBER}

Koentjaraningrat. 2009. Pengantar Ilmu Antropologi. Jakarta: Rineka Cipta.

Kotler, Philip. 1999. Manajemen Pemasaran: Analisis Perencanaan, Implementasi dan Pengendalian. Jakarta: Erlangga. 
Monografi Desa Air Sena, 2017.

Parwitaningsih. 2005. Pengantar

Sosiologi. Jakarta: Universitas Terbuka.

Ritzer, George. 2007. Sosiologi Ilmu Pengetahuan Berparadigma Ganda. Jakarta: Raja Grafindo Kencana.

Ritzer, George. 2012. Teori Sosiologi. Yogyakarta: Pustaka Pelajar.

Silalahi, Ulber. 2009. Metode Penelitian Sosial. Bandung: PT. Rafika Aditama.

Soeprapto, Riyadi. 2007. Teori Interaksi Simbolik. Jakarta: Kencana Pranata.

Sugiyono. 2014. Metode Penelitian Kuantitatif, Kualitatif dan $R \& D$. Bandung: Alfabeta.

Syani, Abdul. 1994. Sosiologi Sistematika, Teori dan Terapan. Jakarta: Bumi Aksara.

Soekanto, Soerjono. 2006. Sosiologi Suatu Pengatar. Jakarta: PT Raja Grafindo Persada.

Utsman, Sabian. 2007. Anatomi Konflik dan Solidaritas Masyarakat Nelayan. Yogyakarta: Pustaka Pelajar.
Wargito. 2003. Psikologi Sosial. Yogyakarta: Andi Offset.

West, Richard dan Lynn H. Tuner, 2008. Pengantar Teori Komunikasi Analisis dan Aplikasi. Jakarta: Salemba Humanika.

Wirawan. 1999. Teori Aplikasi dan Penelitian. Jakarta: Salemba Empat.

Wawancara. Arinandi, Desa Air Sena. 17 Januari 2018.

Wawancara. Laukuto, Desa Air Sena, 15 Januari 2018.

Wawancara. Karyo, Desa Air Sena 21 Januari 2018.

Zen, Muhammad. 2002. Orang Laut Studi Etnopedagogi. Bandung: Mata Production. 
